\title{
PENERAPAN PERENCANAAN PAJAK ATAS PAJAK PENGHASILAN
}

\author{
Bagus Tutuka Wibisono ${ }^{1}$, Novi Swandari Budiarso ${ }^{2}$ \\ ${ }^{1}$ PT. Energy Logistics, R.S. Fatmawati Raya No. 8, Jakarta Selatan, 12420, Indonesia \\ ${ }^{2}$ Program Studi Profesi Akuntan, Fakultas Ekonomi dan Bisnis, Universitas Sam Ratulangi, Jl. Kampus Bahu, \\ Manado, 95115, Indonesia \\ E-mail: bagustutuka@gmail.com ${ }^{1}$
}

\begin{abstract}
This study aims to describe how the implementation of appropriate tax planning in order to minimize the payment of income tax. In optimizing tax planning, a strategy that can be done is to make a nominative list related to entertainment expenses, management of food facilities, health and communication for employees, the use of the gross-up method in calculating employee salaries. Tax planning resulted in tax savings of IDR 7,022,500.00. The available cash flow from the tax savings can be maximized to support other operational activities.
\end{abstract}

Keywords: tax plan; income tax; tax avoidance

\section{PENDAHULUAN}

Kasus perpajakan merupakan salah satu kasus di Indonesia yang memerlukan penanganan serius dari pemerintah karena pajak merupakan sumber utama penerimaan negara. Tanpa adanya pajak maka sebagian besar kegiatan negara akan sulit untuk dilaksanakan, misalnya pembiayaan berbagai proyek pembangunan seperti pembangunan jalan-jalan, jembatan, sekolah, dan rumah sakit. Hal ini mencerminkan bahwa peranan penerimaan pajak bagi negara adalah sangat penting dalam menunjang roda pemerintahan dan pembiayaan pembangunan. Salah satu penerimaan pajak yang memiliki kontribusi terbesar adalah Pajak Penghasilan (PPh) selain Pajak Pertambahan Nilai (PPN), Pajak Bumi Bangunan (PBB), dan Pajak Lainnya. Penerimaan PPh juga berasal dari pajak yang dibayarkan oleh Wajib Pajak badan usaha yang dianggap mengurangi laba badan usaha.

Banyak upaya yang dilakukan oleh badan usaha di Indonesia guna memperkecil jumlah pajak yang dibayarkan, diantaranya adalah pembuatan laporan keuangan ganda dimana laporan keuangan yang sebenarnya akan disimpan oleh pemilik untuk kepentingan pribadi, sedangkan laporan keuangan yang fiktif dibuat sedemikian rupa untuk laporan pajak dan bekerja sama dengan oknum pegawai pajak. Salah satu upaya legal atau tidak melanggar peraturan perpajakan yang dapat dilakukan untuk meminimalkan beban pajak adalah perencanaan pajak (tax planning). Dengan adanya perencanaan pajak, menyebabkan komponen penghasilan kena pajak turun, sehingga $\mathrm{PPh}$ terutang dan $\mathrm{PPh}$ kurang bayar juga turun. Maka perencanaan pajak berdampak positif yaitu badan usaha memiliki dana yang lebih besar yang dapat ditanamkan kembali untuk mengembangkan badan usaha lebih lanjut.

\section{TINJAUAN PUSTAKA}

Undang-Undang Republik Indonesia Nomor 16 Tahun 2009 menyebutkan bahwa pajak adalah kontribusi wajib kepada negara yang terutang oleh orang pribadi atau badan yang bersifat memaksa berdasarkan Undang-Undang, dengan tidak mendapatkan imbalan secara langsung dan digunakan untuk keperluan negara bagi sebesar-besarnya kemakmuran rakyat. Undang-Undang Nomor 36 tahun 2008 Pasal 1 menyatakan bahwa pajak penghasilan dikenakan terhadap orang pribadi atau perseorangan dan badan berkenaan dengan penghasilan yang diterima atau diperolehnya selama satu tahun pajak. Shafer dan Simmons (2006) menjelaskan bahwa wajib pajak cenderung melakukan penghindaran pajak dengan 
tujuan untuk meminimalkan beban pajak dengan memanfaatkan celah-celah ketentuan perpajakan tanpa melakukan pelanggaran atas peraturan tersebut. Rahayu (2010), Inkiriwang (2017), dan Alfaruqi et al. (2019) menyatakan bahwa penghindaran pajak merupakan tindakan yang berbentuk hambatan-hambatan dalam pemungutan pajak sehingga mengakibatkan berkurangnya penerimaan kas negara.

Menurut Pohan (2013:21), tujuan perencanaan pajak adalah: (1) meminimalisasi beban pajak yang terutang; (2) memaksimalkan laba setelah pajak; (3) meminimalkan terjadinya kejutan pajak jika terjadi pemeriksaan pajak oleh fiskus; dan (4) memenuhi kewajiban perpajakan secara benar, efisien, dan efektif sesuai dengan ketentuan perpajakan. Lebih lanjut Pohan (2013:20) menjelaskan bahwa perencanaan pajak memberikan manfaat berupa: (1) penghematan kas keluar; dan (2) mengatur aliran kas masuk dan kas keluar. Muljono (2009:2) menyatakan bahwa perencanaan pajak perlu dilakukan dengan mengikuti metode akuntansi dan peraturan perpajakan yang berlaku. Secara empiris, Deák (2004), Dyreng et al. (2008), dan McLaren (2008) membuktikan bahwa penghindaran pajak adalah segala bentuk kegiatan hukum ditinjau dari peraturan perpajakan yang berpengaruh terhadap kewajiban perpajakan dengan tujuan untuk mengurangi beban perpajakan. Bukti empiris dari Fallan et al. (1995), Nugraha dan Setiawan (2019), Ratnasari dan Nuswantara (2020), dan Damayanti dan Wulandari (2021) menunjukkan bahwa berbagai upaya dilakukan oleh wajib pajak dalam rangka meminimalkan beban pajak dengan tujuan untuk mengoptimalkan laba yang diterima tanpa melakukan pelanggaran atas peraturan yang berlaku.

\section{METODE DAN TEKNIK PENERAPAN IPTEKS}

\subsection{Metode penerapan ipteks}

Penerapan ipteks ini menggunakan metode deskriptif dalam menjelaskan konsep dalam perencanaan pajak.

\subsection{Teknik penerapan ipteks}

Teknik yang dipilih dalam penerapan ipteks ini adalah berbentuk uraian dan simulasi penghitungan dalam menghitung pajak sesuai konsep perencanaan pajak.

\section{PEMBAHASAN}

Strategi untuk menerapkan perencanaan pajak dapat dilakukan melalui beberapa cara. Salah satu cara yang dapat dilakukan adalah dengan mengevaluasi beban yang dikategorikan tidak diperbolehkan sebagai pengurang penghasilan bruto menjadi beban yang diperbolehkan sebagai pengurang penghasilan bruto. Beberapa strategi perencanaan pajak yang dapat diterapkan agar dapat meminimalkan pembayaran pajak penghasilan adalah:

1. Membuat daftar nominatif terkait beban entertainment. Apabila tidak membuat daftar nominatif terkait sebagian beban entertainment sehingga dalam peraturan perpajakan, beban tersebut dianggap fiktif dan harus dikoreksi fiskal positif. Pada dasarnya, beban entertainment diperbolehkan sebagai pengurang penghasilan bruto badan usaha maka strategi perencanaan pajak yang dapat diterapkan adalah harus selalu menyimpan buktibukti pengeluaran terkait beban entertainment dan membuat daftar nominatif yang nantinya dilampirkan dalam Surat Pemberitahuan (SPT) tahunan Pajak Penghasilan $(\mathrm{PPh})$. Hal ini seperti yang diatur dalam Surat Edaran Direktur Jenderal Pajak No. SE334/PJ.3 12/2003 tentang Penegasan atas Biaya Representasi bahwa beban entertainment, representasi, jamuan tamu dan sejenisnya sepanjang untuk mendapatkan, menagih, dan memelihara penghasilan pada dasamya dapat dikurangkan dari penghasilan bruto sebagaimana dimaksud dalam Undang-Undang Nomor 36 tahun 2008 Pasal 6 ayat (1) huruf a. Beban tersebut dapat menjadi komponen pengurang penghasilan bruto dengan syarat badan usaha harus dapat membuktikan bahwa beban tersebut telah benar-benar dikeluarkan dan benar ada hubungannya dengan kegiatan badan usaha untuk 
mendapatkan, menagih, dan memelihara penghasilan badan usaha. Selain itu, badan usaha harus membuat daftar nominatif dan dilampirkan dalam SPT tahunan PPh. Kelebihan dari perubahan ini adalah jumlah beban entertainment secara keseluruhan dapat dijadikan sebagai komponen pengurang penghasilan bruto sehingga dapat mengurangi besarnya penghasilan kena pajak dan pajak penghasilan badan yang terutang.

2. Mengganti pemberian uang makan untuk karyawan menjadi penyediaan makanan dan minuman di kantor. Kebijakan perusahaan terkait dengan kesejahteraan karyawan adalah dengan memberikan uang makan walaupun dalam hal ini perusahaan tidak menyediakan makanan untuk seluruh karyawan di kantor. Beban ini merupakan pemberian kenikmatan dan natura kepada karyawan sehingga harus dikoreksi fiskal positif karena sesuai dengan Undang-Undang Nomor 36 tahun 2008 Pasal 9 ayat (1) huruf e, beban tersebut tidak termasuk dalam komponen pengurang penghasilan bruto. Hal ini menyebabkan strategi perencanaan pajak yang dapat diterapkan oleh perusahaan adalah mengganti pemberian uang makan menjadi penyediaan makanan dan minuman di kantor. Beban yang dikeluarkan untuk penyediaan makanan dan minuman ini menimbulkan akun baru pada laporan laba rugi yaitu beban konsumsi. Kelebihan dari perubahan ini adalah seperti yang diatur dalam Undang-Undang Nomor 36 tahun 2008 Pasal 9 ayat (1) huruf e bahwa pemberian kenikmatan atau natura dalam bentuk penyediaan makanan dan minuman bagi seluruh karyawan dapat dibebankan seluruhnya sehingga tidak perlu dikoreksi fiskal positif. Selain itu, beban tersebut tidak termasuk sebagai tambahan penghasilan bagi karyawan (non-taxable) sehingga tidak dikenakan Pajak Penghasilan Pasal 21.

3. Mengganti beban pengobatan untuk karyawan menjadi pemberian asuransi kesehatan yang selama ini pengeluaran untuk pengobatan ditanggung karyawan. Akibat dari kebijakan ini adalah karyawan dapat berbuat curang dengan mengatasnamakan dirinya pada bon obat dan bukti pendukung lain yang sebenarnya milik orang lain. Jumlah pengeluaran tersebut cenderung berfluktuasi setiap periodenya dan tidak menutup kemungkinan akan menjadi sangat besar pada suatu periode tertentu. Beban pengobatan ini tidak diperbolehkan sebagai komponen pengurang penghasilan bruto badan sehingga harus dikoreksi fiskal positif maka strategi perencanaan pajak yang dapat diterapkan adalah mengikutsertakan karyawan-karyawannya dalam asuransi kesehatan sehingga jika ada karyawan yang sakit, klaim dapat dilakukan ke perusahaan asuransi. Sebagaimana yang diatur dalam Undang Nomor 36 tahun 2008 Pasal 9 ayat (1) huruf d, pengeluaran tersebut dapat dibebankan oleh badan usaha apabila pengeluaran premi asuransi dibayar oleh pemberi kerja (badan usaha) dan besarnya premi tersebut dihitung sebagai penghasilan bagi wajib pajak yang bersangkutan (karyawan). Kelebihan dari perubahan ini adalah beban yang dikeluarkan dapat dijadikan sebagai komponen pengurang penghasilan bruto badan usaha. Selain itu, jumlah beban yang dikeluarkan oleh badan usaha menjadi tetap atau pasti setiap periodenya sehingga laba badan usaha tidak berfluktuasi serta pengeluaran badan usaha menjadi lebih terkontrol. Perubahan ini memiliki kekurangan yaitu pemberian asuransi kesehatan akan meningkatkan Pajak Penghasilan Pasal 21 yang terutang karena merupakan tambahan penghasilan bagi karyawan.

4. Mengganti beban Pajak Penghasilan Pasal 21 yang ditanggung perusahaan ke dalam bentuk tunjangan pajak dengan metode gross-up. Selama ini perusahaan membayar atau menanggung sepenuhnya pajak penghasilan karyawan yang terutang Pajak Penghasilan Pasal 21 dan tidak diberikan dalam bentuk tunjangan. Beban Pajak Penghasilan Pasal 21 yang ditanggung oleh perusahaan merupakan imbalan berupa kenikmatan atau natura sehingga berdasarkan Undang Nomor 36 tahun 2008 Pasal 4 ayat (3) huruf d, fasilitas berupa pajak yang dibayarkan perusahaan tidak termasuk dalam penghasilan bagi karyawan (non-taxable). Selain itu, berdasarkan Undang Nomor 36 tahun 2008 Pasal 9 
ayat (1) huruf e, beban tersebut tidak dapat dijadikan sebagai komponen pengurang penghasilan bruto bagi badan usaha (non-deductible) dan harus dikoreksi fiskal positif. Strategi perencanaan pajak yang dapat ditetapkan adalah memberikan tunjangan pajak dengan metode gross-up. Besarnya tunjangan pajak akan dikelompokkan ke dalam akun gaji dalam hal ini metode gross-up digunakan untuk menyamakan jumlah pajak yang akan dibayar dengan tunjangan pajak yang diberikan badan usaha kepada karyawan. Kelebihan dari perubahan ini adalah berdasarkan Undang Nomor 36 tahun 2008 Pasal 6 ayat (1) huruf a, besarnya tunjangan yang diberikan merupakan beban yang dapat menjadi pengurang penghasilan bruto bagi badan usaha (deductible) sehingga dapat mengurangi penghasilan kena pajak yang dijadikan sebagai dasar perhitungan pajak penghasilan yang terutang.

5. Membuktikan bahwa pemakaian pulsa ponsel sepenuhnya terkait dengan kepentingan usaha. Selama ini perusahaan memberikan fasilitas kepada karyawan bagian penjualan karena jabatan atau pekerjaannya berupa pengisian ulang pulsa ponsel setiap bulan berdasarkan bukti-bukti pembelian yang dilaporkan oleh karyawan yang bersangkutan. Beban pengisian ulang pulsa ponsel yang dipergunakan badan usaha untuk karyawan karena jabatan atau pekerjaannya hanya dapat dibebankan sebesar 50\% dari jumlah pengisian ulang pulsa dalam tahun pajak yang bersangkutan. Hal ini tentu merugikan perusahaan karena beban tersebut hanya boleh diakui sebesar 50\% saja, meskipun jumlah beban tersebut tidak terlalu besar. Selain itu, kekurangan dari kebijakan adalah karyawan dapat berbuat curang yaitu dengan memberikan nota pembelian palsu. Seperti yang di atur dalam Undang Nomor 36 tahun 2008 Pasal 6 ayat (1) bahwa beban untuk mendapatkan, menagih, dan memelihara penghasilan dapat mengurangi penghasilan bruto maka strategi perencanaan pajak yang dapat diterapkan oleh perusahaan adalah membuktikan bahwa pemakaian pulsa ponsel sepenuhnya terkait dengan kepentingan usaha yaitu untuk mendapatkan, menagih, dan memelihara penghasilan. Cara membuktikannya adalah dengan menggunakan sistem pasca bayar, yang mana pembayaran pemakaian pulsa dilakukan di akhir bulan sesuai dengan jumlah pemakaian pulsa dan tentunya badan usaha dapat meminta print data terkait pihak-pihak yang telah dihubungi oleh nomor ponsel tersebut. Kelebihan dari adanya perubahan ini adalah beban pemakaian pulsa ponsel untuk karyawan sepenuhnya atau sebesar $100 \%$ dapat dijadikan sebagai komponen pengurang penghasilan bruto bagi badan usaha.

Setelah mengoptimalkan perencanaan pajak, terjadi beberapa perubahan pada akunakun dan timbulnya akun baru yang ada pada laporan laba rugi. Perubahan tersebut mengakibatkan pengurangan bahkan peniadaan jumlah koreksi fiskal positif pada laporan laba rugi. Tabel 1 menyajikan perbandingan perhitungan fiskal sebelum dan setelah perencanaan pajak. Hasil penghitungan menunjukkan bahwa setelah mengoptimalkan perencanaan pajak maka laba komersial mengalami kenaikan sebesar IDR 4.831.419,00. Hal ini disebabkan adanya strategi yang dilakukan pada akun beban gaji dan Pajak Penghasilan Pasal 21 yang ditanggung perusahaan. Selain itu, jika diasumsikan bahwa tidak ada beban yang dikoreksi fiskal positif maka hal ini dikarenakan adanya strategi yang dilakukan pada akun beban entertainment, gaji, Pajak Penghasilan Pasal 21 yang ditanggung perusahaan, serta telepon, internet, dan fax. Pada penghitungan fiskal, seluruh beban yang dikeluarkan oleh badan usaha diperbolehkan mengurangi penghasilan bruto sehingga dengan diperbolehkannya seluruh beban yang dikeluarkan menjadi pengurang penghasilan bruto maka hal ini mengakibatkan berkurangnya laba fiskal. Hasil penghitungan juga menunjukkan bahwa laba fiskal berkurang sejumlah IDR 56.180.575,00 dan selain itu, telihat bahwa besarnya Pajak Penghasilan Badan terutang berkurang sebesar IDR 7.022.500,00 yang dipengaruhi oleh laba fiskal yang berkurang. Hal ini berarti dengan mengoptimalkan perencanaan pajak maka perusahaan dapat melakukan penghematan pajak yang tentunya 
berkaitan erat dengan penghematan kas yang dikeluarkan oleh badan usaha. Berdasarkan konsep perencanaan pajak, manfaat bagi perusahaan adalah aliran kas yang tersedia dari hasil penghematan pajak tersebut dapat dimaksimalkan untuk mendukung kegiatan operasional yang lain.

Tabel 1. Perhitungan fiskal sebelum dan sesudah perencanaan pajak Sebelum Perencanaan Pajak Setelah Perencanaan Pajak (Dalam IDR) (Dalam IDR)

\begin{tabular}{lrlr}
\hline A.Laba Komersial & 202.127 .691 & A.Laba Komersial & 206.959 .110 \\
B. Koreksi Fiskal & & B. Koreksi Fiskal & \\
1. Koreksi Fiskal Positif & 61.011 .994 & 1. Koreksi Fiskal Positif & \\
2. Koreksi Fiskal Negatif & 12.281 .914 & 2. Koreksi Fiskal Negatif & 12.281 .914 \\
C. Laba Fiskal & 250.857 .771 & C. Laba Fiskal & 194.677 .196 \\
D. PPh Badan Terutang & 31.357 .125 & D. PPh Badan Terutang & $24.334 .62 S$ \\
\hline
\end{tabular}

\section{KESIMPULAN DAN SARAN}

\subsection{Kesimpulan}

Penerapan perencanaan pajak dalam menyusun laporan laba rugi fiskal tanpa disertai strategi perencanaan pajak secara optimal berdampak pada efisiensi dimana terdapat bebanbeban yang sebenarnya dapat dijadikan sebagai pengurang penghasilan bruto. Kajian ini menunjukkan bahwa dampak yang terjadi setelah mengoptimalkan perencanaan pajak yaitu laba komersial mengalami kenaikan. Pengoptimalan perencanaan pajak juga mengakibatkan tidak adanya beban yang dikoreksi fiskal positif. Hal ini berarti seluruh beban yang dikeluarkan oleh badan usaha diperbolehkan mengurangi penghasilan bruto sehingga dengan diperbolehkannya seluruh beban yang dikeluarkan menjadi pengurang penghasilan bruto, maka akan mengakibatkan berkurangnya laba fiskal. Optimalisasi perencanaan pajak menyebabkan terjadinya penghematan pajak sehingga kas hasil penghematan pajak tersebut dapat digunakan untuk mendukung kegiatan operasional yang lain.

\subsection{Saran}

Kajian ini menyarankan agar para wajib pajak sebaiknya membuat daftar nominatif terkait beban entertainment, mengganti pemberian uang makan untuk karyawan menjadi penyediaan makanan dan minuman di kantor, mengganti beban pengobatan untuk karyawan menjadi pemberian asuransi kesehatan, dan mengganti beban Pajak Penghasilan Pasal 21 yang ditanggung perusahaan ke dalam bentuk tunjangan pajak dengan metode gross-up.

\section{DAFTAR PUSTAKA}

Alfaruqi, H. A., Sugiharti, D. K., \& Cahyadini, A. (2019). Peran pemerintah dalam mencegah tindakan penghindaran pajak sebagai aktualisasi penyelenggaraan pemerintahan yang baik dalam bidang perpajakan. Acta Diurnal: Jurnal Ilmu Hukum Kenotariatan, 3(1), 113-133. http://jurnal.fh.unpad.ac.id/index.php/acta/article/view/216

Damayanti, V., \& Wulandari, S. (2021). The effect of leverage, institutional ownership, and business strategy on tax avoidance (Case of listed manufacturing companies in the consumption goods industry period 2014-2019). Jurnal Accountability, 10(1), 16-26. https://doi.org/10.32400/ja.33956.10.1.2021.16-26

Deák, D. (2004). Legal considerations of tax evasion and tax avoidance. Society and Economy, 26(1), 41-85. https://doi.org/10.1556/socec.26.2004.1.2

Dyreng, S. D., Hanlon, M., \& Maydew, E. L. (2008). Long-run corporate tax avoidance. The Accounting Review, 83(1), 61-82. https://doi.org/10.2308/accr.2008.83.1.61 
Fallan, L., Hammervold, R., \& Grounhaug, K. (1995). Adoption of tax planning instruments in bussines organizations: A structural equation modelling approach. Scandinavian Journal of Management, 11(2), 177-190. https://doi.org/10.1016/09565221(95)00007-I

Inkiriwang, K. G. (2017). Perspektif hukum terhadap upaya penghindaran pajak oleh suatu badan usaha. Lex $t$ 13-18. https://ejournal.unsrat.ac.id/index.php/lexetsocietatis/article/view/16072

McLaren, J. (2008). The distinction between tax avoidance and tax evasion has become blurred in Australia: why has it happened?. Journal of the Australasian Tax Teachers Association, $3(2)$, 141-163. https://static1.squarespace.com/static/5e88791f0c333872e0b33272/t/5ee61f83b3fb18 39cc35bbbe/1592139679422/JATTA-2008-Volume3-Issue2-All-Articles.pdf

Muljono, D. (2009). Tax planning: Menyiasati pajak dengan bijak. Yogyakarta: Penerbit ANDI.

Pohan, C. A. (2013). Manajemen perpajakan: Strategi perencanaan pajak dan bisnis. Jakarta: PT. Gramedia Pustaka Utama.

Nugraha, M. C. J., \& Setiawan, P. E. (2019). Pengaruh penghindaran pajak (tax avoidance) pada nilai perusahaan dengan transparansi sebagai variabel pemoderasi. E-Jurnal Akuntansi, 26(1), 398-425. https://doi.org/10.24843/EJA.2019.v26.i01.p15

Rahayu, N. (2010). Evaluasi regulasi atas praktik penghindaran pajak penanaman modal asing. Jurnal Akuntansi dan Keuangan Indonesia, 7(1), 61-78. http://dx.doi.org/10.21002/jaki.2010.04

Ratnasari, D., \& Nuswantara, D. A. (2020). Pengaruh kepemilikan institusional dan leverage terhadap penghindaran pajak (tax avoidance). Jurnal Akuntansi AKUNESA, 9(1), 110. https://journal.unesa.ac.id/index.php/akunesa/article/view/9392

Shafer, W., \& Simmons, R. (2008). Social responsibility, machiavellianism and tax avoidance: A Study of Hong Kong tax professionals. Accounting, Auditing \& Accountability Journal, $21(5), \quad 695-720$. http://dx.doi.org/10.1108/09513570810872978

Undang-Undang Republik Indonesia Nomor 16 Tahun 2009 tentang Penetapan Peraturan Pemerintah Pengganti Undang-Undang Nomor 5 Tahun 2008 Tentang Perubahan Keempat Atas Undang Undang Nomor 6 Tahun 1983 Tentang Ketentuan Umum Dan Tata Cara Perpajakan Menjadi Undang-Undang.

Undang-Undang Republik Indonesia Nomor 36 Tahun 2008 tentang Perubahan Keempat Atas Undang-Undang Nomor 7 Tahun 1983 Tentang Pajak Penghasilan. 